\title{
STRATEGY OF BUSINESS DEVELOPMENT BAMBOO CRAFT (A Study in Pasirjambu Village Pasirjambu District Bandung Regency)
}

\author{
Encep Sopandi \\ Lecture at Departement of Business Administration Science, \\ Faculty of Social and Political Science, Nurtanio University Bandung \\ Email: sopandi07@yahoo.com
}

\begin{abstract}
This study aims to determine alternative strategies in the development of bamboo handicrafts business in Pasirjambu Village Pasirjambu District in Bandung Regency. Method used survey with SWOT analysis. The results show that the total value obtained from the IFAS table is 6.40 (average 3.20) with a strength score of 3,550 and the weakness score of 2.850, it shows that the strength factor of the bamboo handicraft business is greater than the weakness factor, while the total value EFAS of 6.10 (average 3.05). A opportunity score of 3.10 and a threat score of 3.0. This means that the opportunity factor is greater than the threat factor. The result of calculation of rating value and internal factor weight of bamboo handicraft business development strategy in Pasirjambu Village as $X$ axis equal to 0,100, while external factor as $Y$ axis equal to 0,700. This means the right alternative strategy is the SO strategy. The SO strategy is a strategy that uses the power to take advantage of existing opportunities.
\end{abstract}

Keywords : Bamboo craft, craftmanship of bamboo, SWOT analysis

\section{STRATEGI PENGEMBANGAN USAHA KERAJINAN BAMBU (Studi di Desa Pasirjambu Kecamatan Pasirjambu Kabupaten Bandung)}

\begin{abstract}
ABSTRAK
Penelitian ini bertujuan untuk mengetahui strategi alternatif dalam pengembangan usaha kerajinan bambu di Desa Pasirjambu Kecamatan Pasirjambu Kabupaten Bandung. Metode yang digunakan survey dengan analisis SWOT. Hasil, menunjukkan bahwa total nilai yang diperoleh dari tabel IFAS adalah 6,40 (rata-rata 3,20) dengan skor kekuatan 3,550 dan skor kelemahan sebesar 2,850, ini menunjukkan bahwa faktor kekuatan usaha kerajinan bambu lebih besar dari faktor kelemahan, sedangkan total nilai EFAS yaitu sebesar 6,10 (rata-rata 3,05). Skor peluang 3,10 dan skor ancaman sebesar 3,0. Artinya faktor peluang yang dimiliki lebih besar dari faktor ancaman. Hasil perhitungan nilai rating dan bobot faktor internal dari strategi pengembangan usaha kerajinan bambu di Desa Pasirjambu sebagai sumbu X sebesar 0,100, sedangkan faktor eksternal sebagai sumbu Y sebesar 0,700. Artinya strategi alternatif yang tepat adalah strategi SO. Strategi SO adalah strategi yang menggunakan kekuatan untuk memanfaatkan peluang yang ada.
\end{abstract}

Kata kunci : Kerajinan bambu, perajin bambu, analisis SWOT 


\section{PENDAHULUAN}

Bambu di Indonesia berlimpah. Indonesia memiliki $12 \%$ koleksi bambu dunia, namun kenyataan menunjukkan bahwa pemanfaatan bambu di negara kita kalah dibanding dengan negara-negara lain yang tidak memiliki banyak bambu. Hal ini disinyalir karena keterbatasan pengetahuan SDM dari para perajin bambu dan masih ada anggapan sebagian masyarakat bahwa bambu sebagai simbol kemiskinan. Dampaknya, produk-produk kerajinan bambu pun kurang diperhatikan oleh masyarakat. (Mukoddas, Medanbisnis, 2014).

Perkembangan terkini, menunjukkan fenomena positif dari komoditas dan produkproduk kerajinan bambu yang laku keras di pasaran domestik dan ekspor. Meningkatnya kembali penggunaan produk bambu, terjadi seiring dengan tren "kembali ke alam" yang semakin digemari masyarakat dunia, termasuk Indonesia. Usaha kerajinan bambu kembali bangkit dengan pemasaran dan produk yang terus berkembang. Fenomena ini memunculkan sinergi antara perkembangan selera, pasokan bahan baku, lapangan kerja dan tertunjangnya upaya pelestarian lingkungan, serta menjaga kearifan lokal.

Pasirjambu dan Ciwidey Kabupaten Bandung selain terkenal dengan wisata alam Cimanggu, Kawah Putih dan agrowisata Stawberry, dikenal pula dengan kerajinan bambunya. Terlihat di sepanjang jalan arah Pasirjambu Ciwidey jejeran batangan bambu dan produk anyaman bambu. Hasil penelusuran menunjukkan sebagian masyarakat Pasirjambu dan Ciwidey adalah perajin bambu. Banyak produk kerajinan bambu hasil karya perajin asal Pasirjambu dan Ciwidey, seperti produk anyaman bilik, giribig, mebel bambu, rumah bambu gazebo, lesehan dan sejenisnya.

Kerajinan bambu di Pasirjambu sudah ada sejak tahun 1970-an. Namun menurut Ate, salah seorang perajin di RW. 01 Kampung Kabuyutan yang penulis temui. Usaha ini stagnan, “...dari dulu sampai sekarang tidak ada kemajuan." Ate mengatakan bahwa jumlah perajin menurun, anak muda jarang yang mau melanjutkan usaha kerajinan bambu, mereka lebih tertarik bekerja di bidang usaha lain. “...anak muda di Pasirjambu hampir rata-rata memilih bekerja di pabrik atau konveksi." Ate berpendapat kurangnya minat generasi muda melanjutkan usaha kerajinan bambu dikarenakan usaha kurang menarik, pekerjaannya lama, rumit dan uangnya tidak seberapa. Sehubungan dengan kondisi lapangan tersebut, penulis tertarik melakukan penelitian untuk mengetahui sejauhmana "Pengembangan Usaha Kerajinan Bambu di Desa Pasirjambu Kecamatan Pasirjambu Kabupaten Bandung."

\section{TINJAUAN PUSTAKA}

\section{Konsep Strategi}

Strategi merupakan suatu cara perusahaan atau organisasi untuk mencapai tujuan jangka panjangnya. (Wheleen and Hunger, 2012). Strategi adalah tindakan yang bersifat incremental (senantiasa meningkat) dan terus menerus, serta dilakukan berdasarkan sudut pandang tentang apa yang diharapkan oleh para pelanggan di masa depan. (Hamel and Prahalad, 1997).

Strategi dapat berupa suatu rencana atau tindakan yang terdiri dari aturan atau pola pengambilan keputusan yang berkaitan dengan aktivitas bisnis dan posisi untuk mencapai tujuan yang akan datang. Titik berat pada sumber daya yang dimiliki, sehingga dapat menentukan atau menghubungkan posisi perusahaan dengan lingkungan bisnis di mana perusahan dijalankan.

Strategi bisnis bermanfaat dalam proses pelaksanaan pekerjaan dengan menggunakan semua sumberdaya yang secara nyata dimiliki, melalui proses yang terintegrasi dengan fungsi bisnis lainnya serta dapat dinilai hasilnya berdasarkan tujuan organisasi.

Para pelaku bisnis (perajin atau pengusaha kerajinan bambu) dalam menyusun strategi perlu memperhatikan aktivitas-aktivitas berikut: (1) penentuan misi perusahaan atau organisasi, (2) mengenali peluang dan ancaman eksternal, (3) 
menetapkan kekuatan dan kelemahan internal, (4) menetapkan tujuan jangka panjang, (5) menghasilkan strategi laternatif, (6) menetapkan strategi pokok yang perlu diimplementasikan. (David, 2007).
Aplikasi strategi berdasarkan konsep David (2007) dilakukan melalui pendekatan berupa matriks dengan tiga tahapan, yaitu: Tahapan input, tahapan pencocokan, dan tahapan pengambilan keputusan sebagaimana terlihat pada gambar 1 .

\section{Gambar 1 Tahapan Analisis Perumusan Strategi}

\begin{tabular}{|l|l|l|l|}
\hline TAHAP 1, TAHAP MASUKAN \\
\hline $\begin{array}{l}\text { Matrik Evaluasi Faktor Eksternal } \\
\text { (EFE) }\end{array}$ & $\begin{array}{l}\text { Matrik } \\
\text { Kompetitif/Persaingan }\end{array}$ & $\begin{array}{l}\text { Matrik Evaluasi Faktor Internal } \\
\text { (IFE) }\end{array}$ \\
\hline TAHAP 2, TAHAP PENCOCOKAN & Matrik IE & Matrik Grand Strategy \\
\hline Matrik SWOT & Matrik SPACE & Matrik BCG & \\
\hline TAHAP 3, TAHAP KEPUTUSAN \\
\hline Matrik QSPM (Quantitative Stategic Planning Matrix) \\
\hline
\end{tabular}

Sumber : David (2007: 102)

\section{Konsep Pengembangan Usaha}

Pengembangan usaha dalam penelitian ini disama artikan dengan pengembangan bisnis. Pengembangan bisnis adalah penciptaan peluangpeluang baru melalui pendekatan baru dan berbeda (Eades, 2003 dalam Klump and Koppers, 2009).

Perusahaan yang potensial berkembang biasanya menghadapi lebih dari satu peluang, oleh karena itu penting bagi perusahaan untuk menentukan prioritas. Analisis terhadap berbagai peluang adalah merupakan fungsi dari bagian pengembangan usaha, sehingga apabila hasil analisis menunjukkan bahwa peluang yang ada berharga dan penting untuk kemajuan perusahaan, maka realisasikan.

Pengembangan bisnis adalah penciptaan nilai jangka panjang sebuah organisasi/perusahaan dari konsumen, pasar, dan relasi. Pengembangan bisnis adalah segala hal yang berkaitan dengan bagaimana interaksi dari faktor-faktor tersebut berkombinasi bersama-sama untuk menciptakan peluang tumbuh (Pollack, 2012).

Pengembangan bisnis mendeskripsikan sebuah fungsi bisnis yang dibangun secara menyeluruh dalam perusahaan. Pengembangan bisnis melibatkan semua aktifitas yang bertujuan untuk menciptakan nilai dan potensial revenue untuk perusahaan, mengembangkan produk dan teknologi sehingga dapat dikomersialkan, dan membangun hubungan dengan partner potensial, konsumen dan stakeholders lainnya, serta memelihara dan meningkatkan hubungan untuk kepentingan perusahaan (Kind, 2007).

\section{Analisis SWOT}

Analisis SWOT (Strenghts, Weaknesses, Opportunity, Threaths) memberikan informasi yang bermanfaat untuk mencocokkan sumberdaya dan kemampuan dengan lingkungan kompetitif di mana organisasi usaha beroperasi. Model ini dapat digunakan untuk merancang dan memilih strategi, dan dapat diaplikasikan dalam setiap situasi pengambilan keputusan, asalkan tujuan sudah didefinisikan dengan jelas. (Assen, et.al, alih bahasa Susanto, 2013 : 77).

Cara penggunaan analisis SWOT. Langkah pertama adalah mengidentifikasi kekuatan, kelemahan, peluang dan ancaman yang dialami perusahaan. Pengamatan terhadap lingkungan internal dan eksternal merupakan bagian penting dari proses. Kekuatan dan kelemahan merupakan faktor internal, dimana perusahaan dapat mengontrol faktor ini. Sementara peluang dan ancaman adalah faktor eksternal yang terkadang sulit dikontrol, seperti munculnya para pesaing dan dinamika pasar. 
Gambar 2 Strategi dalam Analisis SWOT

\begin{tabular}{|c|l|l|l|}
\hline $\begin{array}{c}\text { SWOT } \\
\text { Analisis }\end{array}$ & \multicolumn{2}{|c|}{ Kekuatan (S) } & \multicolumn{2}{c|}{ Kelemahan (W) } \\
\hline Peluang (O) & $\begin{array}{l}\text { Strategi-strategi S-O. Gunakan } \\
\text { kekuatan untuk memanfaatkan } \\
\text { peluang }\end{array}$ & $\begin{array}{l}\text { Strategi-strategi W-O. Manfaatkan } \\
\text { peluang denganmengatasi kelemahan } \\
\text { atau membuatnya jadi relevan }\end{array}$ \\
\hline Ancaman (T) & $\begin{array}{l}\text { Strategi-strategi S-T. Gunakan } \\
\text { kekuatan untuk menghindari } \\
\text { ancaman }\end{array}$ & $\begin{array}{l}\text { Strategi-strategi S-W. Minimalisasi } \\
\text { kelemahan dan hindari ancaman }\end{array}$ \\
\hline
\end{tabular}

Sumber : Assen, et.al, alih bahasa Susanto, 2013 : 77

Setelah analisis internal dan eksternal, hasil dapat ditempatkan dalam matriks konfrontasi. Matrik konfrontasi berisi daftar kekuatan, kelemahan, peluang dan ancaman, dengan poin untuk setiap kombinasi. Semakin penting kombinasi tersebut, semakin banyak poin yang diberikan. Konfrontasi ini mengarah pada identifikasi isu-isu strategis utama organisasi yang seringkali mendesak.

\section{Gambar 3 Matriks Konfrontasi SWOT}

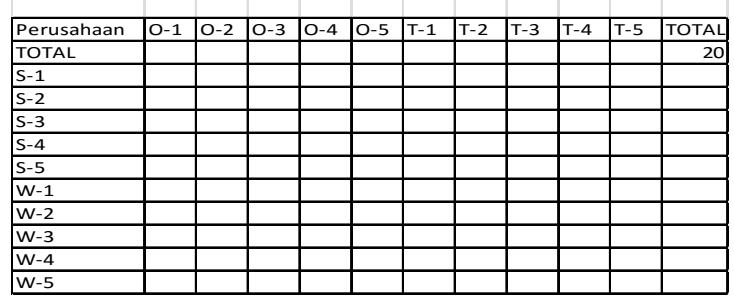

Sumber : Sumber : Assen, et.al, alih bahasa Susanto, 2013 : 79

Langkah-langkah dalam analisis SWOT terdiri dari tiga tahap sebagai berikut:

\section{Tahap 1: Deteksi isu-isu strategis}

1. Identifikasi masalah-masalah eksternal yang relevan terhadap ;posisi strategis perusahaan dalam industri dan lingkungan pada umumnya, dengan pengertian bahwa peluang dan ancaman adalah faktor-faktor yang tidak dapat dipengaruhi oleh manajemen secara langsung

2. Identifikasi masalah-masalah internal yang relevan terhadap posisi strategis perusahaan

3. Analisis dan urutkan masalah-masalah eksternal berdasarkan probabilitas dan dampak
4. Buatlah daftar isu-isu strategis dan faktor dari dalam atau luar organisasi yang secara signifikan memengaruhi posisi kompeteitif dalam matrik SWOT

\section{Tahap 2: Tentukan Strategi}

5. Identifikasi strategi yang cocok bagi perusahaan, dengan mempertimbangkan kemampuan internal dan lingkungan eksternal perusahaan

6. Rumuskan strategi-strategi alternative untuk mengatasi isu-isu utama

7. Tempatkan strategi-strategi alternatif ke salah satu dari empat kuadran dalam matriks SWOT:

a. S-O: kekuatan internal dikombinasikan dengan peluang eksternal. Adalah kombinasi yang ideal, tetapi ini membutuhkan pemahaman bagaimana kekuatan internal dapat mendukung kelemahan di daerah lain;

b. W-O: kelemahan internal dikombinasikan dengan peluang harus dinilai dari efektifitas investasi untuk menentukan apakah keuntungan yang diperoleh sebanding dengan upaya untuk membeli atau mengembangkan kemapuan internal;

c. S-T: kekuatan internal dikombinasikan dengan ancaman eksternal membutuhkan pengetahuan untuk mengadaptasi organisasi dalam rangka mengbah ancaman menjadi peluang;

d. W-T: kelemahan internal dikombinasikan dengan ancaman menciptakan scenario terburuk 
perubahan-perubahan radikal seperti divestasi diperlukan.

8. Kembangkan strategi tambahan untuk setiap "blind spot" yang tersisa dalam matriks SWOT.

9. Pilih strategi yang tepat

\section{Tahap 3: Implementasi dan Pantau Strategi}

10. Kembangkan rencana tindakan untuk mengimplementasikan strategi SWOT

11. Tetapkan tanggungjawab dan anggaran

12. Pantau kemajuan

13. Mulai proses pengkajian dari awal.

\section{Kerajinan Bambu}

Kerajinan (kriya) merupakan bagian dari seni rupa terapan yang merupakan titik temu antara seni dan desain yang bersumber dari warisan tradisi atau ide kontemporer yang hasilnya dapat berupa karya seni, produk fungsional, benda hias dan dekoratif, serta dapat dikelompokkan berdasarkan material dan eksplorasi alat teknik yang digunakan, dan juga dari tematik produknya. (Kementrian Parekraf, 2014: 58)

Bambu sebagai salah satu bahan kerajinan merupakan tanaman dengan beragam manfaat. "serumpun bambu, sejuta makna, sejuta manfaat dan sejuta karya." (Naggamiharja, 2012).

Manfaat bambu antara lain: untuk bahan baku berbagai macam industri, bahan konstruksi, dan biofuel. Pemanfatan bambu sebagai bahan baku industri antara lain, pembuatan tusuk gigi, sumpit, korek api, kertas, furniture, aneka anyaman, alat musik, pewarna alami, dan makanan. Bambu dapat dibuat sebagai bahan kerajinan, baik kerajinan yang sifatnya fungsional atau aksesoris. (Widjaja, 2012).

\section{Kerangka Pemikiran Penelitian}

\section{Gambar 4 Kerangka Pemikiran Penelitian}

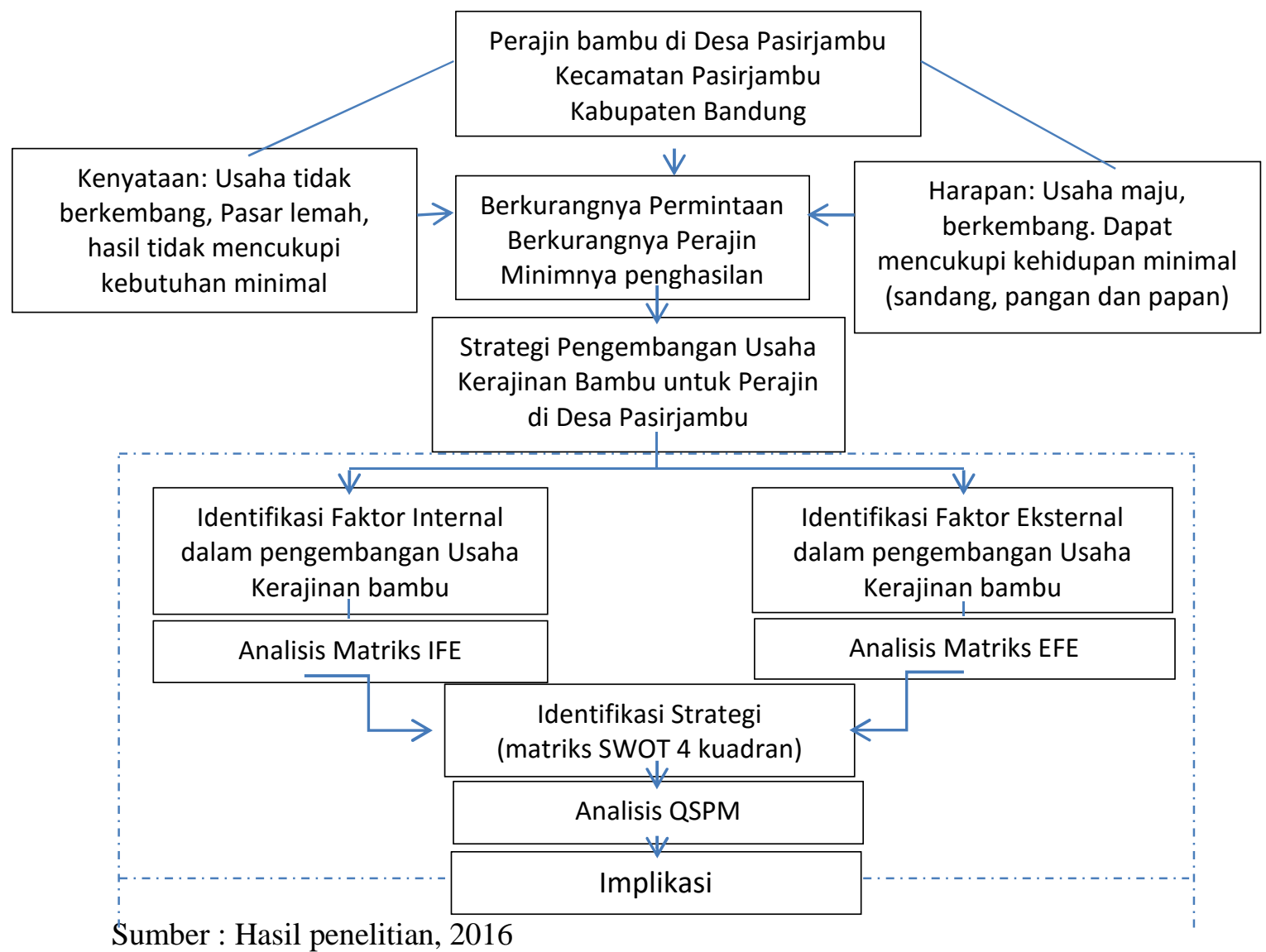




\section{METODE PENELITIAN}

Pelaksanaan penelitian menggunakan desain kualitatif dengan metode survey dan analisis deskriptif, yaitu metode untuk menjelaskaan bagaimana usaha kerajinan bambu dilakukan dan srtategipengembangannyaseperti apa, sekaligusmenganalisis faktor-faktor yangmempengaruhinya.Salah satu ciri pendekatan penelitian kualitatif adalah menjadikan peneliti sebagai instrumen utama. Sebagai instrumen penelitian, maka peneliti melakukan wawancara, pengamatan, pendalaman atas pengamatan dan apabila diperlukan dapat menyelenggarakan Forum Group Discussion (FGD) serta melakukan analisis dokumen.

Data yang dibutuhkan peneliti, dikumpulkan menggunakan alat bantu sebagai kelengkapan instrumen, antara lain adalah:Pedoman wawancara;Alat Perekam;Camera (Photo).

Selanjutnya adalah kegiatan triangulasi, yaitu teknik pengumpulan data yang bersifat menggabungkan dari berbagai cara dan sumber data yang telah ada. Peneliti mengumpulkan data sekaligus menguji kredibilitas data dengan berbagai teknik dari berbagai sumber data, juga pengumpulan data yang berbeda-beda dari sumber yang sama. Triangulasi dilakukan sampai data jenuh, artinya data dari sumber sudah relatif sama dan tidak ada lagi data yang baru.

Teknik pengolahan dan analisis data dilakukan dalam beberapa tahapan sebagai berikut :Mengorganisasikan Data; Pengelompokan berdasarkan kategori, tema dan pola jawaban; Menguji Asumsi atau Permasalahan yang ada terhadap Data; Mencari Alternatif Penjelasan bagi Data; Menulis Hasil Penelitian.

Jenis dan sumber datapenelitian ini diperoleh dari informan kunci, yaitu sumber yang mengetahui seluk beluk usaha kerajinan bambu di Desa Pasirjambu, yaitu Kepala Desa, Tokoh perajin, dan pengusaha kerajinan bambu di Desa Pasirjambu. Penelitian ini menggunakan dua jenis data, yaitu data primer dan data skunder yang berkaitan dengan topik penelitian. Data primer diperoleh dari hasil wawancara. Sedangkan data skunder melalui literatur tertulis yang diperoleh dari berbagai sumber relevan.

Tabel 2 Jenis dan Sumber Data

\begin{tabular}{|c|c|c|}
\hline \multicolumn{2}{|r|}{ Jenis Data } & Sumber Data \\
\hline $\begin{array}{l}\text { Data } \\
\text { Primer }\end{array}$ & $\begin{array}{l}\text { Kondisi usaha kerajinan bambu saat ini } \\
\text { Faktor-faktor yang menjadi kekuatan, } \\
\text { kelemahan, peluang dan tangangan usaha } \\
\text { kerajinan bambu. Penentuan bobot dan } \\
\text { peringkat dari setiap faktor. Penentuan dari } \\
\text { niali kemenarikan dari setiap alternative } \\
\text { strategi }\end{array}$ & $\begin{array}{l}\text { Pengusaha kerajinan/perajin } \\
\text { Key informan/pakar terdiri dari: } \\
\text { Pengusaha kerajinan bambu; Kepala Desa; } \\
\text { Tokoh perajin; Perajin terahli; } \\
\text { Dinas Koperasi dan Perdagangan Kab. } \\
\text { Bandung; Yayasan Bambu Indonesia }\end{array}$ \\
\hline $\begin{array}{l}\text { Data } \\
\text { Skunder }\end{array}$ & $\begin{array}{l}\text { Perkembangan usaha kerajinan bambu di } \\
\text { Kabupaten Bandung. Jumlah perajin } \\
\text { bambu di Kabupaten Bandung. Jumlah } \\
\text { IKM bambu di Kabupaten Bandung. Nilai } \\
\text { pe njualan usaha kerajinan bambu di Desa } \\
\text { Pasirjambu }\end{array}$ & $\begin{array}{l}\text { Dinas Koperasi dan Perdagangan Kab. } \\
\text { Bandung; Desa Pasirjambu; Pengusaha } \\
\text { Kerajinan bambu di Desa Pasirjambu }\end{array}$ \\
\hline
\end{tabular}

Sumber: Hasil penelitian, 2016.

HASIL DAN PEMBAHASAN

\section{Karakteristik Masyarakat Desa Pasirjambu}

Masyarakat Desa Pasirjambu Kecamatan
Pasirjambu Kabupaten Bandung sebagian besar $80 \%$ bermatapencaharian sebagai petani dan selebihnya adalah pedagang, buruh pabrik dan aneka usaha lainnya. Untuk yang bertani, disela- 
sela kegiatan, setelah pulang dari sawah dan ladang, umumnya mengisi kegiatan warisan turun temurun, yaitu kegiatan kerajinan bambu.

Asep Hamdani, SH., Kepala Desa Pasirjambu yang saat ini menjabat untuk periode ke-3 mengatakan:

“...masyarakat di sini, dari dulu sampai kini terkenal dengan kerajinan bambu, bahkan orang tua saya, buyut saya, itu adalah tokoh kerajinan di sini, boleh dikatakan 'juragan'nya, karena semua perajin menjualnya ke orang tua saya" ujarnya menjelaskan. "bahkan saya, sampai saat ini, disamping menjadiKepala Desa, saya masih berusaha dari kerajinan bambu, yang dijalankan oleh istri dan saudara-saudara saya."

Kepala Desa Pasirjambu menjelaskan seiring dengan perkembangan jaman usaha kerajinan bambu di wilayah Pasirjambu-Ciwidey mulai menurun, hal ini disebabkan dari daya tarik usaha ini terkalahkan oleh daya tarik pabrik, konveksi dan usaha lain, sehingga mulai dari tahun 90-an kerajinan bambu kurang diminati oleh generasi muda, namun demikian usaha kerajinan ini tidak padam, sehingga terlihat sampai saat ini masih ada dan bertahan.

Asep Hamdani menjelaskan, masyarakat di desa Pasirjambu yang masih menggeluti usaha kerajinan bambu adanya di RW. 01 RT. 01 Kampung Kabuyutan, untuk wilayah RW lain, memang ada, namun tidak seperti di RW. 01 yang hampir seluruhnya masih menggeluti usaha kerajinan bambu. Jumlah perajin di RW 01 ada sekitar $40 \mathrm{KK}$, kerajinan yang diproduksi adalah bilik, mebel bambu (meja, kursi), dan ada pula pesanan membuat saung bambu, joglo dan lesehan.

\section{Analisis Lingkungan Eksternal}

Analisis lingkungan eksternal dalam pengembangan usaha kerajinan bambu bertujuan untuk mengevaluasi kecenderungan dan kejadian yang berada di luar kontrol para perajin/pengusaha kerajinan. Analisis lingkungan eksternal berfokus pada penentuan faktor-faktor kunci yang menjadi peluang dan tantangan bagi usaha kerajinan bambu di Desa Pasirjambu Kecamatan Pasirjambu Kabupaten Bandung sehingga diharapkan memudahkan bagi perajin/usaha kerajinan bambu untuk menentukan strategi dalam meraih peluang dan mengatasi ancaman, dengan demikian, pihak perajin mampu mengidentifikasi serangkaian faktor-faktor strategis yang menjadi penentu dalam penyusunan strategi pengembangan usaha.Analisis lingkungan eksternal umumnya dilihat dari beberapa aspek, antara lain: aspek politik/kebijakan pemerintahan, aspek ekonomi, aspek sosial, aspek budaya dan aspek teknologi.

Faktor politik atau kebijakan pemerintah. Salah satu faktor yang menonjol dan berpengaruh terhadap industri bambu nasional adalah adanya deklarasi bambu nasional yang dikeluarkan tahun 2012. Pemerintah melalui beberapa kementerian mulai fokus pada potensi bambu nasional. Tanggal 23 Oktober 2012 telah telah terbit deklarasi bambu nasional, "Pengembangan Industri Bambu Nasional Dalam Rangka Meningkatkan Ekonomi Kerakyatan Berkelanjutan," yang ditandatangani oleh tiga kementerian yaitu: Kementerian Perenencanaan dan Pembangunan Nasional (BAPPENAS), Kementerian Kehutanan, dan Kementerian Perindustrian. Pemerintah bertekad menggali manfaat bambu untuk menjadi komoditi unggulan nasional sehingga memiliki nilai ekonomi yang tinggi bagi masyarakat Indonesia, mengingat selama ini pengembangannya secara nasional belum fokus, terpadu dan optimal.

Faktor Ekonomi, Indonesia merupakan pasar potensial, karena jumlah penduduk ke 4 terbesar di dunia dengan kisaran 237,6 juta jiwa (BPS 2010). Menurut catatan, laju pertumbuhan ekonomi Indonesia di tahun 2010 - 2011 mencapai 6,2 - 6,5 dimana peran terbesar pendorong laju pertumbuhan ekonomi nasional adalah permintaan domestik akan barang dan jasa yang mencapai $70 \%$ dari pendapatan domestic bruto (PDB). Organisations for Economics Cooperation and Development (OECD) sebagai organisasi dunia yang mengawasi pertumbuhan ekonomi dunia memperkirakan pertumbuhan 
ekonomi Indonesia rata-rata untuk jangka menengah dan panjang (2012 - 2016) akan menjadi yang tertinggi di antara Negara-negara ASEAN.

Jumlah penduduk yang banyak dan laju pertumbuhan yang tinggi menunjukkan bahwa Indonesia adalah pasar yang sangat potensial, dan ini berdampak pula pada daerah, baik untuk tingkat provinsi, kabupaten/kota bahkan sampai ke desa/kelurahan. Oleh karena itu, sudah seharusnya pengusaha di Indonesia menjadikan pasar dalam negeri sebagai sasaran pasar yang harus dimanfaatkan secara optimal, kalau tidak, maka akan dimanfaatkan oleh perusahaan asing dan produk luar negeri. Berkenaan dengan kerajinan bambu, para perajin dengan difasilitasi pemerintah dapat memperhatikan dinamika ekonomi yang terjadi sehungga usaha kerajinannya berkembang dengan fokus pasar dalam negeri.

Faktor sosial, budaya, demografi dan lingkungan masyarakat. Indonesia memiliki beraneka ragam budaya, tata kehidupan sosial dan lingkungan masyarakat yang cukup kaya. Misalnya dalam hal kerajinan bambu, dari jenis dan bentuk kerajinan, untuk setiap daerah sangat beraneka ragam, menurut $\mathrm{H}$. Jatnika lebih dari 110 jenis ragam anyaman dari berbagai daerah di Indonesia. Dalam hal memanfaatkan bahan bambu, bisa dibuat dalam berbagai ragam karya; bisa dengan seni ukir, seni anyam, seni rangkai (rumah dan furniture). Hal inilah yang menjadi sumber kekayaan masyarakat Indonesia. Namun demikian, sumberdaya alam dan sumberdaya sosial budaya, sebegai asset belum dimanfaatkan secara optimal.

Tidak dapat disangkal bahwa sebagian besar masyarakat Indonesia lebih banyak menyukai produk impor (luar negeri) dibanding produk masyarakat sendiri (dalam negeri). Masalah yang paling besar yang dihadapi masyarakat Indonesia (sampai ke daerah) adalah belum menempatkan prioritas (mengutamakan) memilih produk domestik, hasil karya masyarakat sendiri sebagai pilihan dalam belanja, bahkan tidak masuk dalam kategori top of mind, dan lebih miris lagi, cenderung melihat dengan sebelah mata terhadap produk-produk kerajinan dari bambu. Masih ada anggapan di masyarakat Indonesia, khusus kabupaten Bandung, bahwa bambu identik dengan kemiskinan.

Berdasarkan hasil identifikasi faktor-faktor eksternal pada usaha kerajinan bambu, dapat diperoleh beberapa faktor untuk meningkatkan keberlangsungan usaha kerajinan bambu di Desa Pasirjambu Kecamatan Pasirjambu Kabupaten Bandung sebagai berikut:

Tabel 3 Identifikasi Faktor Eksternal Usaha Kerajinan Bambu di Desa Pasirjambu

\begin{tabular}{|c|c|c|c|}
\hline No & Aspek & Faktor & Peluang/Ancaman \\
\hline \multirow[t]{3}{*}{1} & $\begin{array}{l}\text { Poitik, Kebijakan } \\
\text { Pemerintah, Peraturan } \\
\text { (Hukum) }\end{array}$ & $\begin{array}{l}\text { Deklarasi bambu nasional tahun } 2012 \text { sebagai } \\
\text { titik tolak berbagai kebijakan tentang } \\
\text { pengembangan bambu nasional }\end{array}$ & Peluang \\
\hline & & $\begin{array}{l}\text { Kesepakatan perdagangan internasional, } \\
\text { regional ACFTA. CAFTA }\end{array}$ & Ancaman \\
\hline & & Kebijakan pengurusan HAKI & Ancaman \\
\hline \multirow[t]{2}{*}{2} & Ekonomi & $\begin{array}{l}\text { Penduduk Indonesia yang cukup banyak (pasar } \\
\text { potensial) }\end{array}$ & Peluang \\
\hline & & $\begin{array}{l}\text { Peningkatan tingkat ekonomi masyarakat } \\
\text { (tumbuhnya kelas menengah) }\end{array}$ & Peluang \\
\hline \multirow[t]{4}{*}{3} & $\begin{array}{l}\text { Sosial, Budaya, Demografi } \\
\text { dan Lingkungan masyarakat }\end{array}$ & $\begin{array}{l}\text { Kebudayaan yang beraneka ragam, terutama } \\
\text { jenis kerajinan bambu }\end{array}$ & Peluang \\
\hline & & Indonesia penghasil bambu terbesar ke 3 dunia & Peluang \\
\hline & & $\begin{array}{l}\text { Masyarakat Indonesia lebih menyukai produk } \\
\text { asing (luar negeri) }\end{array}$ & Ancaman \\
\hline & & $\begin{array}{l}\text { Kolaborasi antara perajin, pemerintah dan dunia } \\
\text { usaha }\end{array}$ & Peluang \\
\hline
\end{tabular}

Sumber : Hasil penelitian, 2016. 


\section{Analisis Lingkungan Internal}

Analisis lingkungan internal usaha kerajinan bambu di Desa Pasirjambu Kecamatan Pasirjambu Kabupaten Bandungdigunakan untuk mengetahui sejauhmana kemampuan perajin dalam mengembangkan usaha sehingga dapat berkembang dan maju. Analisis lingkungan internal adalah analisis berdasarkan faktorfaktor yang berasala dari dalam perushaan sendiri dan umumnya dapat dikendalikan oleh perushaan. Lingkungan internal merupakan proses identifikasi terhadap faktor-faktor yang menjadi kekuatan dan kelemahan suatu perusahaan. Proses internal perusahaan tersebut dianalisis dengan menggunakan pendekatan fungsional, yaitu analisis yang dilakukan oleh masing-masing fungsi dalam perusahaan dengan mengkaji aspek sumberdaya manusia, pemasaran, keuangan/akuntansi, produksi, inovasi serta pemanfaatan sumber informasi/penggunaan sumber informasi.

Faktor sumberdaya manusia. Usaha kerajinan bambu di Desa Pasirjambu Kecamatan Pasirjambu Kabupaten Bandung dilakukan oleh para perajin sendiri. Perajin sebagai pemilik dari usaha kerajinannya, sehingga proses pengambilan keputusan apa pun dilakukan oleh sendiri. Menurut hasil wawancara dengan sdr. Ate di RT.01 RW. 01
Kampung Kabuyutan, perajin di daerahnya, berusaha sendiri, dan hasilnya dijual langsung ke konsumen, namun ada pula yang menjual kepada pengepul/Bandar.

Perajin di desa pasirjambu dalam melakukan usahanya masih tradisonal, artinya belum menggunakan manajemen usaha yang menerapkan prinsip-prinsip pengelolaan usaha yang terencana, terorganisasi, melainkan masih kebiasaan turun-temurun. Siklusnya, ada pesanan, buat, selesai, kirim dan mendapatkan pembayaran.

Faktor pemasaran. Pemasaran hasil kerajinan bambu di Desa Pasirjambu Kecamatan Pasirjambu Kabupaten Bandung sudah dilakukan sampai ke luar negeri, yaitu dilakukan oleh pengepul/Bandar. Menurut Asep Hamdani sebagai pengusaha kerajinan bambu di Desa Pasirjambu, ia pernah mendapatkan pesanan dan melakukan pengiriman barang sampai ke Malaysia, Mesir dan Abu Dhabi. Produk yang dipesan adalah mebel bambu.

Untuk pasar domestik, perajin di Desa Pasirjambu telah mendapatkan pelanggan dari beberapa daerah, yaitu Bandung Raya (Kota Bandung, Cimahi dan Bandung Barat). Harga dari produk kerajinan bambu dari Desa Pasirjambu dapat dilihat pada tabel 4 sebagai berikut:

Tabel 4 Kisaran Harga Produk Kerajinan Bambu di Desa Pasirjambu

\begin{tabular}{|c|l|c|r|}
\hline No & \multicolumn{1}{|c|}{ Nama Produk } & Satuan & \multicolumn{1}{|c|}{$\begin{array}{c}\text { Kisaran Harga } \\
\text { (Rp.) }\end{array}$} \\
\hline 1 & Bilik Biasa (bagian dalam bambu/daging bambu) & M2 & $7.500-10.000$ \\
2 & Bilik Hinis (bagian luar bambu/hinis bambu) & M2 & $15.000-20.000$ \\
& & & \\
3 & Bilik hias (Bambu motif) & M2 & $25.000-30.000$ \\
4 & Tempat tidur & Set & $750.000-900.000$ \\
5 & Kursi & Set & $750.000-1.200 .000$ \\
6 & Saung/Joglo/Lesehan & M2 & $1.000 .000-1.500 .000$ \\
\hline
\end{tabular}

Sumber: Hasil penelitian, 2016.

Faktor keuangan. Modal dari usaha kerajinan bambu berasal dari dana pribadi para perajin. Terkadang, untuk modal usaha, perajin menggunakan dari uang muka pemesanan, terutama untuk membeli bahan baku. Belum ada bantuan kredit dari bank atau lembaga keuangan lain. Modal masih terbatas dari para perajin sendiri.

Faktor bahan produksi. Bahan baku yang dibutuhkan oleh para perajin adalah bambu 
dengan ukuran diameter 5-8 $\mathrm{cm}$ untuk mebel, dan diameter 10-12 cm untuk bahan anyaman. Bahan baku diperoleh dari petani yang ada di sekitar daerah Ciwidey, kecuali untuk bambu hitam didatangkan dari Garut. Harga perbatang dengan ukuran diameter $10-12 \mathrm{~cm}$ adalah $\mathrm{Rp}$. 10.000 - 20.000; dan untuk ukuran 5-8 cm adalah Rp. 7.500-15.000. Bambu hitam di kisaran Rp. 15.000 - 20.000. Produksi dilakukan di rumah perajin, dan hasil produksi berupa stok disimpan di Bandar/pengepul.

Faktor inovasi. Perajin di Desa Pasirjambu belum melakukan usaha yang lebih memperhatikan faktor perkembangan kebutuhan pasar lebih luas. Mereka melakukan usaha kerajinan yang sudah biasa dilakukan. Mengapa mereka tidak membuat produk model lain, jawabannya tidak mau berspekulasi dan barang tidak laku dijual, lebih baik yang sudah pasti lakunya, artinya yang sudah biasa dibuat. Kebutuhan dapur yang mendesak, adalah alasan utama mereka.

Berdasarkan identifikasi faktor-faktor internal maka dapat dilihat hasil inventarisasi sebagaimana pada tabel berikut:

Tabel 5 Identifikasi faktor internal usaha kerajinan bambu di Desa Pasirjambu

\begin{tabular}{|l|l|l|l|}
\hline No & Aspek & Faktor & Kekuatan/Kelemahan \\
\hline 1 & $\begin{array}{l}\text { Sumberdaya } \\
\text { Manusia }\end{array}$ & $\begin{array}{l}\text { Pengambilan keputusan pengembangan usaha masih } \\
\text { didominasi perajin sendiri, belum menggunakan } \\
\text { prinsip manajemen usaha profesional }\end{array}$ & Kelemahan \\
\hline 2 & Pemasaran & $\begin{array}{l}\text { Sebagian besar perajin berusia tua dan berpendidikan } \\
\text { SD dan SMP }\end{array}$ & Kelemahan \\
\hline & & Pernah menjual ke luar negeri & Kekuatan \\
\hline & & $\begin{array}{l}\text { Variasi Produk yang ditawarkan masih itu-itu saja } \\
\text { (tidak ada inovasi) }\end{array}$ & Kelemahan \\
\hline 3 & Keuangan & Modal sendiri yang sangat terbatas & Kelemahan \\
\hline 4 & Produksi & Bahan bambu masih mudah diperoleh & Kekuatan \\
\hline 5 & Inovasi & $\begin{array}{l}\text { Tidak ada terobosan pembuatan produk sesuai dengan } \\
\text { perkembangan lingkungan (desain baru) }\end{array}$ & Kelemahan \\
\hline
\end{tabular}

Sumber: Hasil penelitian, 2016.

\section{Evaluasi Faktor Ekternal dan Internal}

Berdasarkan analisis lingkungan eksternal yang telah dikemukakan, maka diperoleh beberapa faktor strategis eksternal untuk pengembangan usaha kerajinan bambu di Desa Pasirjambu Kecamatan Pasirjambu Kabupaten Bandung yang merupakan peluang dan ancaman.

Faktor eksternal yang menjadi peluang adalah: 1) keseriusan pemerintah (pemerintah daerah Kabupaten Bandung) untuk meningkatkan daya saing nasional bambu sebagai tindak lanjut dari deklarasi bambu nasional; 2) Indonesia, Jawa Barat, lebih khusus Bandung Raya adalah pasar potensial, dengan jumlah penduduk yang cukup tinggi; 3) meningkatnya kelas menengah; 4) kekayaan budaya, ragam anyaman dan ragam seni kerajinan di Indonesia; 5) Indonesia merupakan penghasil bambu terbesar ke tiga dunia. Adapun faktor strategis eksternal sebagai ancaman adalah: 1) Kesepakan dagang dunia maupun regional ACFTA yang mengakibatkan banyaknya produk luar negeri masuk Indonesia sebagai pesaing, dengan harga yang murah; 2) budaya masyarakat Indonesia yang lebih menghargai produk asing (luar negeri); 3) lemahnya HAKI untuk produk kerajinan; 4). Kemampuan menyerap informasi perkembangan desain produk kerajinan bambu nasional.

Evaluasi faktor Internal menghasilkan beberapa faktor strategis internal berupa kekuatan dan kelemahan pada usaha pengembangan kerajinan bambu di Desa Pasirjambu Kecamatan Pasirjambu Kabupaten Bandung. Beberapa faktor strategis internal 
yang menjadi kekuatan adalah: 1) semangat dari para perajin untuk menjalankan usaha. 2) memilik pengalaman menjual produk ke luar negeri, 3) bahan baku bambu masih banyak dan mudah diperoleh. Adapun faktor strategis internal yang menjadi kelemahan adalah: 1) pengambilan keputusan masih belum berdasarkan profesionalisme, 2) usia tua dan tingkat pendidikan perajin rendah. 3) modal sendiri yang terbatas, 4) tidak ada inovasi produk.

\section{Analaisis SWOT}

\section{1) Tahapan Masukan (Input Stage)}

Tahapan masukan terdiri dari penyusunan matriks IFE (internal factor evaluation) dan matriks EFE (external factor evaluation). Analisi kedua matriks tersebut dibuat berdasarkan hasil identifikasi kekuatan
(Strenght), kelemahan (Weaknesses), sebagai faktor internal dan faktor-faktor eksternal yang terdiri dari peluang (Opportunities) dan ancaman (Threats).

Faktor strategis eksternal dari usaha kerajinan bambu di Desa Pasirjambu Kecamatan Pasirjambu Kabupaten Bandung yang meliputi peluang (Opportunities) dan ancaman (Threats), kemudia dilakukan pengisian berdasarkan hasil wawancara.Matrik EFE digunakan untuk mengetahui seberapa besar peranan dan faktor-faktor eksternal berupa peluang dan ancaman yang dihitung berdasarkan bobot dan nilai yang diambil.

Hasil analisis matriks EFE untuk usaha kerajinan bambu di desa Pasirjambu Kecamatan Pasirjambu Kabupaten Bandung dapat terlihat pada tabel 6 sebagai berikut:

\section{Tabel 6 Analisis matriks EFE Kerajinan Bambu Desa Pasirjambu}

\begin{tabular}{|c|c|c|c|}
\hline Faktor Strategis Eksternal & Bobot & Peringkat & $\begin{array}{c}\text { Nilai } \\
\text { Tertimbang }\end{array}$ \\
\hline \multicolumn{4}{|l|}{ 1.PELUANG } \\
\hline $\begin{array}{l}\text { Deklarasi bambu nasional sebagai titik tolak berbagai kebijakan } \\
\text { tentang pengembangan bambu nasional }\end{array}$ & 0,225 & 3 & 0,675 \\
\hline Penduduk Indonesia yang cukup banyak (pasar potensial) & 0,225 & 4 & 0,900 \\
\hline Peningkatan ekonomi masyarakat (tumbuhnya kelas menengah) & 0,175 & 3 & 0,525 \\
\hline $\begin{array}{l}\text { Kebudayaan yang beraneka ragam, terutama jenis kerajinan } \\
\text { bamboo }\end{array}$ & 0,125 & 3 & 0,375 \\
\hline Indonesia penghasil bambu terbesar ke 3 dunia & 0,125 & 3 & 0,375 \\
\hline Kolaborasi antara perajin, pemerintah dan dunia usaha & 0,125 & 2 & 0,250 \\
\hline Total Peluang & 1 & & 3,100 \\
\hline \multicolumn{4}{|l|}{ 2.ANCAMAN } \\
\hline Kesepakatan perdagangan internasional, regional ACFTA. & 0,325 & 3 & 0,975 \\
\hline Kebijakan pengurusan/ kepemilikan HAKI & 0,325 & 3 & 0,975 \\
\hline Masyarakat Indonesia lebih menyukai produk asing (luar negeri) & 0,35 & 3 & 1,050 \\
\hline Total Ancaman & 1 & & 3,00 \\
\hline
\end{tabular}

Sumber : Hasil penelitian, 2016.

Berdasarkan matrik EFE dapat diketahui bahwa faktor stretgis peluang yang memiliki nilai tertimbang tertinggi sebesar 0,900 adalah bahwa Indonesia merupakan pasar potensial dengan jumlah penduduk yang cukup tinggi. Faktor peluang dengan nilai terendah adalah kolaborasi antara pemerintah, dunia usaha dan perajin itu sendiri. Faktor eksternal berupa ancaman tertinggi adalah kebanyakan masyarakat kita menyukai produk impor sebesar 1,050 dilemahkan pula oleh kesepakatan ACFTA dimana produk impor masuk membanjiri Negara Indonesia dan lemahnya kepemilikan HAKI dari produk kerajinan bambu di Indonesia.

Analisis selanjutnya adalah analisis matriks IFE (internal factor evaluation). Penyusunan matriks IFE didasarkan pada faktor strategis 
internal yang meliputi kekuatan dan kelemahan yang dimiliki usaha kerajinan bambu di desa Pasirjambu Kecamatan Pasirjambu Kabupaten Bandung. Faktor-faktor tersebut diperoleh hasil wawancara dengan informan dan diisikan dalam matrik IFE. Bobot akhir yang digunakan dalam matrik adalah bobot rata-rata, sedangkan peringkat akhir yang digunakan adalah nilai peringkat terbanyak sesuai hasil wawancara dengan informan. Hasil analaisis IFE untuk usaha kerajinan bambu di desa Pasirjambu dapat dilihat pada tabel 7 berikut:

Tabel 7 Analisis matriks IFE Kerajinan Bambu Desa Pasirjambu

\begin{tabular}{|l|c|c|c|}
\hline \multicolumn{1}{|c|}{ Faktor Strategis Eksternal } & Bobot & Peringkat & Nilai Tertimbang \\
\hline 1. KEKUATAN & 0,225 & 2 & 0,450 \\
\hline Pernah menjual ke luar negeri & 0,775 & 4 & 3,10 \\
\hline Bahan bambu masih mudah diperoleh & 1 & & 3,550 \\
\hline \multicolumn{1}{|c|}{ Total Kekuatan } & 0,175 & 3 & 0,525 \\
\hline 2. KELEMAHAN & 0,150 & 2 & 0,300 \\
\hline $\begin{array}{l}\text { Pengambilan keputusan pengembangan usaha } \\
\text { masih didominasi perajin sendiri, belum } \\
\text { menggunakan prinsip manajemen usaha } \\
\text { professional }\end{array}$ & 0,250 & 3 & 0,750 \\
\hline $\begin{array}{l}\text { Sebagian besar perajin berusia tua, berpendidikan } \\
\text { SD dan SMP }\end{array}$ & 0,250 & 3 & 0,750 \\
\hline Tidak ada target & 0,175 & 3 & 0,525 \\
\hline $\begin{array}{l}\text { Produk yang ditawarkan masih itu-itu saja } \\
\text { variasi produk lemah) }\end{array}$ & 1 & & 2,850 \\
\hline Modal sendiri yang sangat terbatas & \multicolumn{2}{|c|}{} \\
\hline \multicolumn{1}{|c|}{ Total Kelemahan } & & \\
\hline
\end{tabular}

Sumber: Hasil penelitian, 2016.

Berdasarkan matrik IFE dapat diketahui bahwa kekuatan dari usaha kerajinan bambu di desa Pasirjambu Kecamatan Pasirjambu Kabupaten Bandung adalah bahwa bahan bambu untuk produk kerajinan masih mudah diperoleh dengan nilai tertimbang 3,100. Faktor tertimbang kekuatan terlemah adalah memiliki pengalaman bahwa produk kerajinan dari Pasirjambu ini pernah diekspor ke luar negeri yaitu ke Dubai, Mesir dan Malaysia, dengan nilai tertimbang 0,450 .

\section{2) Tahap Pencocokan (Matching Stage)}

Tahap kedua dalam perumusan strategi adalah tahap pencocokan (matching stage) yang berfungsi untuk mengkombinasikan kekuatan dan kelemahan sebagai faktor internal yang terdapat pada usaha kerajinan bambu dipadukan dengan peluang dan ancaman dari lingkungan eksternal. Dalam penelitian ini analisis yang digunakan adalah matrik SWOT (Strenght,
Weaknesses, Opportunities, Threats) 4 kuadran untuk menghasilkan alternatif strategi pengembangan usaha kerajinan bambu di Desa Pasirjambu Kecamatan Pasirjambu Kabupaten Bandung.

Alternatif strategi yang dihasilkan oleh analisis SWOT 4 kuadran berdasarkan faktorfaktor strategis eksternal berupa peluang dan ancaman serta faktor-faktor strategis internal berupa kekuatan dan kelemahan untuk pengembangan usaha kerajinan bambu di Desa Pasirjambu Kecamatan Pasirjambu Kabupaten Bandung. Hasil akhir dari anlisis ini adalah perumusan alternatif strategi. Strategi dipilih dengan memanfaatkan kekuatan dan peluang secara optimal dan secara simultan mengendalikan kelemahan dan ancaman yang dihadapi.

Posisi dalam matriks SWOT 4 kuadran diperoleh dengan cara memperhitungkan selisih 
nilai tertimbang antara variable peluang dan ancaman dalam matriks EFE sekaligus selisih nilai tertimbang variable kekuatan dan kelemahan dalam matriks IFE. Selisih nilai terimbang dapat dilihat pada tabel 8 berikut:

Tabel 8 Selisih tertimbang berdasarkan matriks EFE dan IFE Usaha Kerajinan Bambu Desa Pasirjamnbu

\begin{tabular}{|l|r|}
\hline \multicolumn{1}{|c|}{ Faktor EFE dan IFE } & Nilai Terimbang \\
\hline Peluang & 3,100 \\
Ancaman & 3,000 \\
\hline Selisih nilai tertimbang & 0,100 \\
\hline Kekuatan & 3,550 \\
Kelemahan & 2,850 \\
\hline Selisih nilai tertimbang & 0,700 \\
\hline
\end{tabular}

Sumber: Hasil penelitian, 2016

Berdasarkan tabel 8 dapat diketahui bahwa nilai tertimbang peluang 3,100 lebih besar daripada ancaman 3,00 sehingga menghasilkan selisih tertimbang positif 0,100 . Begitu juga dengan nilai tertimbang kekuatan sebesar 3,550 lebih besar daripada nilai tertimbang ancaman 2,850 sehingga menghasilkan selisih 0,700. Kedua nilai tersebut kemudian dipasangkan ke dalam matriks SWOT 4 kuadran untuk menentukan posisi usaha seperti yang terlihat pada gambar 5 berikut:

Gambar 5 Posisi Usaha Kerajinan Bambu di Desa Pasirjambu

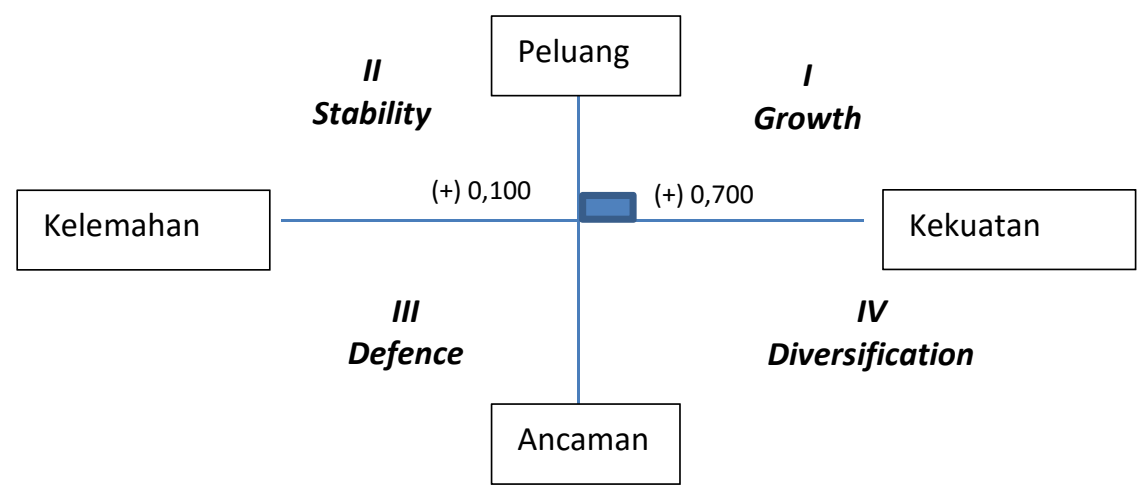

Berdasarkan gambar 5 di atas dapat diketahui bahwa usaha kerajinan bambu di Desa Pasirjambu Kecamatan Pasirjambu Kabupaten Bandung berada di kuadran I, walau pun nilainya kecil 0,100 dan 0,700 . Artinya strategi yang cocok untuk digunakan oleh perajin adalah strategi pertumbuhan/pengembangan sesuai dengan kekuatan yang dimilki dan peluang yang tersedia. Perajin harus berusaha mengembangkan usaha dengan memanfaatkan keunggulan yang dimilki untuk lebih dieksplorasi menjadi lebih kuat dan berkembang.

Usaha yang berada di kuadran I menunjukkan kondisi tumbuh, sehingga memungkinkan untuk terus berkembang secara maksimal. Strategi pertumbuhan meliputi: pengembangan pasar, pengembangan produk dan integrasi dengan pihak terkait, yaitu pemerintah, dunia usaha dan para perajin itu sendiri.

\section{3) Penentuan Strategi Prioritas}

Penentuan strategi prioritas dilakukan dengan menggunakan Quantitative Strategic Planning Matrix (QSPM). Strategi prioritas yang dihasilkan oleh QSPM merupakan srtategi yang diandalkan dan menjadi prioritas untuk menghadapi peluang dan ancaman serta kekuatan dan kelemahan yang dimiliki oleh perusahaan. Melalui analisis QSPM, alternative 
tersebut diprioritaskan berdasarkan tingkat keterkaitan pada lingkungan internal dan eksternal usaha pengrajin bambu sehingga alternatif tersebut dapat dilakukan berdasarkan tingkatan prioritas kepentingannya. Tabel 9 dibawah ini menunjukan hasil perhitungan
QSPM sehingga dihasilkan prioritas strategi alternatif perusahaan. Prioritas strategi dilakukan berdasarkan tingkat kepentingan atau urgensi terhadap masalah yang dihadapi oleh perusahaan.

Tabel 9 Hasil Perhitungan QSPM

\begin{tabular}{|l|c|c|}
\hline \multicolumn{1}{|c|}{ Strategi alternatif } & TAS & Urutan prioritas \\
\hline Membuat produk yang lebih baik & 10,345 & 1 \\
\hline Ikut serta promosi melalui pameran & 7,803 & 3 \\
\hline Menciptakan variasi produk & 9,756 & 2 \\
\hline
\end{tabular}

Sumber : Hasil penelitian, 2016.

Berdasarkan tabel diatas. Hasil matriks QSPM menunjukan bahwa prioritas utama strategi alternatif yang dapat dilakukan oleh usaha pengrajin bambu adalah melakukan inovasi produk TAS terbesar yaitu membuat produk yang lebih baik 10,345 . Prioritas strategi tersebut dipilih berdasarkan tingkat kesesuaian dengan faktor-faktor stategis internal dan eksternal yang didapat dari tahapan sebelumnya. Stategi prioritas selanjutnya yang dapat dilakukan usaha pengrajin bambu secara berurutan adalah strategi menciptakan variasi produk, tidak hanya bilik, tapi produk lainnya yang diminati oleh pasar, dan selanjutnya adalah strategi pasar melalui ikut serta dalam kegiatan pameran-pameran yang diselenggarakan Pemda atau Dinas Instansi terkait.

Strategi yang menjadi prioritas pertama adalah melakukan peningkatan kualitas produk. Tujuan dari stategi ini adalah untuk menghasilkan produk yang sesuai dengan kebutuhan konsumen dalam negeri. Strategi ini dilakukan untuk menangkap peluang utama bahwa Indonesia merupakan pasar potensial dan untuk mengatasi ancaman utama yaitu kesepakatan ACFTA yang berakibat pada banyaknya produk luar negeri yang beredar di Indonesia. Indonesia adalah pasar yang sangat potensial, namun jika tidak waspada, maka pasar potensial tersebut akan mengkonsumsi berbagai produk mancanegara yang dapat dengan mudahnya ditemukan dalam negeri.
Peningkatan kulaitas sebagai daya saing produk lokal merupakan kunci untuk memenuhi kebutuhan pasar domestik ditengah gempuran produk impor. Strategi yang menjadi prioritas pertama ini dapat dilakukan dalam waktu jangka pendek, yaitu tahun 2016. Hal tersebut dikarenakan para perajin/pengusaha kerajinan harus menyediakan beberapa alat dan bahan untuk membuat bambu dengan teknik laminasi. Selain itu, pengusaha dan perajin harus mempelajari dan melakukan uji coba dalam pembuatan bambu dengan teknik laminasi.

Prioritas strategi kedua adalah strategi penciptavariansi produk. Tujuan dari strategi ini adalah agar masyarakat mengenal lebih banyak produk kerajinan dari usaha pengrajin bambu. Strategi ini dilakukan dengan memanfaatkan kekuatan utama yang dimiliki oleh perusahaan yaitu produk yang berkualitas. Dengan menciptakan variasi prosuk maka konsumen dapat membedakan produk usaha pengrajian bambu dengan produk lain. Selain itu melalui penggunaan variansi dapat mengatasi kelemahan harga yang lebih tinggi dari pesaing. Apabila perusahaan telah memiliki banyak jenis produk, maka dapat membangun minat konsumen melalui variansi produk tersebut. Sehingga konsumen tidak lagi mempermasalahkan jenis dan harga yang lebih tinggi.

Prioritas strategi terakhir adalah pengembangan pasar melalui pembukaan outlet promosi baru. Strategi pengembangan pasar 
dengan membuka outlet promosi di Bandung dan Bali dimaksudkan agar produk lebih dikenal dan mudah dijangkau oleh masyarakat. Strategi pengembangan pasar ke Bandung dapat dilakukan pada jangka menengah antara tahun 2015 sampai 2016. Strategi ini dilakukan setelah perusahaan membuat furniture dari bambu laminasi, membuat produk ekslusif, dan menciptakan merek produk. Sedangkan pembukaan outlet promosi diBali dilakukan dalam jangka waktu panjang yaitu setelah tahun 2016. Hal ini dikarenakan banyaknya stakeholder yang akan terlibat dalam proyek pendirian kampung banbu tersebut. Stakeholder yang akan terlibat dalam pendirian kampung bambu tersebut antara lain: pemerintah daerah Bali, masyarakat, dan para pengusaha bambu.

Tabel 10 Implikasi Manajerial Usaha Pengrajin Bambu

\begin{tabular}{|c|c|c|c|c|c|}
\hline Srategi & $\begin{array}{c}\text { JK.Pendek } \\
\text { ( 2016) }\end{array}$ & $\begin{array}{c}\text { JK.Me } \\
\text { nengah } \\
(2016- \\
2017)\end{array}$ & $\begin{array}{c}\text { JK.Panjang } \\
>2018\end{array}$ & Implikasi Manajerial & $\begin{array}{c}\text { Penanggung } \\
\text { jawab }\end{array}$ \\
\hline $\begin{array}{l}\text { Meningkatkan } \\
\text { kualitas } \\
\text { produk }\end{array}$ & $\checkmark$ & & & $\begin{array}{l}\text { Menyediakan alat dan bahan } \\
\text { untuk pembuatan kerajinan } \\
\text { bambu lebih berkualitas } \\
\text { 1. Menyiapkan bahan yang } \\
\text { berkualitas } \\
\text { 2. Menyiapkan alat yang } \\
\text { memadai } \\
\text { 3. Melakukan kontrol atas } \\
\text { pekerjaan yang dilakukan } \\
\text { 4. Mengecek hasil sesuai } \\
\text { standar yang telah } \\
\text { ditentukan }\end{array}$ & Pemilik/perajin \\
\hline $\begin{array}{l}\text { Penciptaan } \\
\text { variansi } \\
\text { produk }\end{array}$ & $\checkmark$ & & & $\begin{array}{l}\text { 1. Membuat jenis/ ragam } \\
\text { kerajinan yang sesuai } \\
\text { dengan produk,singkat, } \\
\text { mudah dan modern. } \\
\text { 2. Menginventaisasi model } \\
\text { dan jenis yang dapat } \\
\text { dibuat oleh perajin }\end{array}$ & Pemilik/perajin \\
\hline $\begin{array}{l}\text { Pemasaran } \\
\text { melalui } \\
\text { kegiatan } \\
\text { Pameran }\end{array}$ & & $\checkmark$ & & $\begin{array}{lr}\text { 1. Membuat } & \text { kerjasama } \\
\text { dengan pihak lain yang } \\
\text { dapat mempromosikan } \\
\text { kerajinan di resa } \\
\text { Pasirjambu, reperti } \\
\text { dengan } \\
\text { Perusahaan dan Sanggar } \\
\text { Seni (Saung Angklung } \\
\text { Udjo) } \\
\text { 2. Ikut serta pameran }\end{array}$ & Pemilik/perajin \\
\hline $\begin{array}{l}\text { Branding } \\
\text { Usaha } \\
\text { Kerajinan } \\
\text { Bambu } \\
\text { Pasirjambu }\end{array}$ & & & $\sqrt{ }$ & $\begin{array}{lr}\text { Membuat usaha kerajinan } \\
\text { bambu di desa Pasrjambu } \\
\text { lebih dikenal oleh } \\
\text { masyarakat luas, bukan } \\
\text { hanya dalam negeri } \\
\text { melainkan sampai luar negeri } \\
\text { (remainding untuk pasar } \\
\text { Abudhabi, Mesir, Malaysia) }\end{array}$ & $\begin{array}{l}\text { Pemilik/perajin } \\
\text { kolaborasi } \\
\text { dengan } \\
\text { pemerintah dan } \\
\text { dunia usaha. }\end{array}$ \\
\hline
\end{tabular}

Sumber: Hasil penelitian, 2016 


\section{SIMPULAN}

\section{Simpulan}

Pengembangan usaha kerajinan bambu di Desa Pasirjambu Kecamatan Pasirjambu Kabupaten Bandung dapat disusun berdasarkan hasil analisis strategi yang merupakan arah langkah untuk mengembangkan bisnis, paling tidak untuk pasar didalam negeri. Program yang disusun difokuskan pada hasil analisis SWOT yang menghasilkan ketiga prioritas strategi yang telah dirimuskan. Implikasi manajerial disusun dalam perumusan kebijakan perusahaan serta langkah-langkah yang harus dilakukan oleh perajin/pengusaha kerajinan.

\section{Saran}

1) Perajin disarankan untuk melakukan pengembangan produk melalui peningkatan kualitas, seperti membuat aneka bilik bambu dan mebel bambu dengan teknik finishing laminasi;

2) Pembuatan produk eksklusif. Perajin harus membuat desain yang bagus, elegan serta menyediakan bahan baku yang berkualitas.

3) Pameran. Perajin harus berusaha melakukan promosi, antara lain melaui kegiatan pameran- pameran, baik mandiri atau ikutserta dengan pihak lain .

\section{DAFTAR PUSTAKA}

\section{A. Buku}

Affuah, A. 2004. Business Models: A Strategic Management Approach. NewYork:

McGraw Hill

Cravens, David Wand Nigel. F Piercy. 2013.

Strategic Marketing. $10^{\text {th }}$ Edition.

NewYork: McGraw-Hill.

Creswell., JhonW.(2009). Research Design:

Qualitative, Quantitative, and Mixed

Methods Approaches (3rd Edition). Sage

Publications.

David, Fred R. (2004). Manajemen Strategis.

PT. Indeks kelompok Gramedia, Jakarta.

D’Aveni, Richard, A.and RobertGunther. 1994.

Hypercompetition: Managing the

dynamics of strategic maneuvering,

NewYork: Maxwell MacmillanInc.
Gerbono, Anton, Djarijah, A.S., 2009. Aneka

Kerajinan Bambu. Yogyakarta. Penerbit

Kanisius.

Ireland, R. Duane, Robert E.Hoskisson, \& Michael A.Hitt. 2009. The Management of Strategy: Concepts and Cases ( $8^{\text {th }}$ Edition). Ohama: South-Western Cengage Learning

Porter, Michael E.1993. Keunggulan Bersaing: Menciptakan dan Mempertahankan Kinerja Unggul. Alih Bahasa Agus Dharma, dkk. Jakarta. Penerbit Erlanga

Sutrisno, Bambang. 2010. Rumah Bambu: Arsitektur Khas Jawa Barat. Jakarta. Pustaka RumahKebun.

Usmara, A. 2003. Implementasi Manajemen Stratejik: Kebijakan dan Proses. Jogjakarta. Penerbit Amara Books.

Wheelen, Thomas L.,\& Hunger,J.David.2012. Strategic Management and business policy: Concepts.13th ed. Pearson Prientice Hall

\section{B. Jurnal}

Edy Suandi Hamid dan Y. Sri Susilo, 2011. Strategi Pengembangan Usaha Mikro Kecil dan Menengah di Provinsi Daerah Istimewa Yogyakarta. JurnalEkonomi Pembangunan. Vol. 12 Nomo2 1, Juni 2011, hal 45-55.

Feigenbaum, A and A. Karnani. 1991. Output Flexibility. A Competitive Advantage for Small Firm. Strategic Manajemen Journal. Vol. 12, pp 101-114.

Rahmana, Arif., Yani Iriani, dan Riena Oktariana. 2012. Strategi Pengembangan Usaha Kecil Menengah Sektor Industri Pengolahan.

JurnalTeknikIndustriUniversitasWidyatam a. Vol. 13 No. 1 Februari 2012.Hal. 14 - 21.

Sri Susilo, Y. 2010. Strategi Meningkatkan Daya Saing UMKM dalam Menghadapi Implementasi CAFTA dan MEA. BuletinEkonomi, Vol 8, No. 2 Agustus 2010, hal.70-78.

Sriana, Jaka. 2010. Strategi Pengembangan Usaha Kecil danMenengah (UKM): Studi Kasus di Kabupaten Bantul. SimposiumNasional 2010: Menuјu 
PurwerejoDinamisdanKreatif. Hal. 79 - 90

\section{Dokumen}

BAPPEDA JABAR, 2015. Laporan Fasilitasi

Pengembangan Ekonomi Kreatif Jawa Barat 2014.

BPS, 2010, 2013, 2014. Jawa Barat Dalam

Angka, Penerbit BPS Jabar

Perdagangan, Kementerian, 2008.

Pengembangan Ekonomi Kreatif Indonesia

2025 Rencana Pengembangan Ekonomi

Kreatif Indonesia 2009-2015, Studi Industri

Kreatif Indonesia, Kementerian

Perdagangan RepublikIndonesia

\section{Elektonik}

hhttp://Okezone.

Com/Athurtian/2014/

EkonomiKreatif/ download 21 Oktober 2014.

http://macammakati.blogspot.com/2011/Produ
kKerajinanBambu, download 11 Agustus 2014

http://www.itb.ac.id/20/03/2012/ProdukKreatif Bambu, download 12 Agustus 2014

http://bamboosaindonesia.multiply.com/12 Agustus 2010/ download 15 September 20154

http://www.opensubscriber.com/19 September 2006/ download 15 September 2014

http://webcache.googleusercontent.com/downl oad 15 September 2014

\section{E. Surat Kabar}

HarianPikiran Rakyat, (12/05/2009, 03/06/2013, 11/07/2014, 10/12/2014, $9 / 5 / 2015,6 / 12 / 2015$ )

Harian Kompas, ( 1/9/2014, 14/10/2014, $11 / 10 / 2016)$ 